
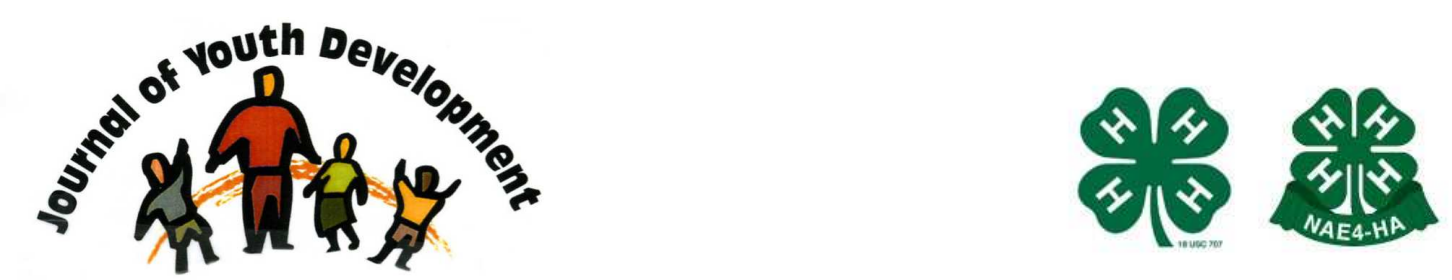

Bridging Research \& Practice

\title{
Combating Youth Violence Through Anti-Violence Coalitions in Three West Virginia Counties
}

\author{
Ronda Sturgill \\ University of Tampa \\ Tampa, FL \\ rsturgill@ut.edu \\ Bob Barnett \\ Marshall University \\ Huntington, WV \\ Lysbeth Barnett \\ Barnett Ink
}




\title{
JOURNAL OF YOUTH DEVELOPMENT \\ bridging research and practice

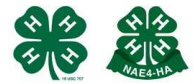

Volume 6, Number 1, Spring 2011

Article 110601FA004

\section{Combating Youth Violence Through Anti-Violence Coalitions in Three West Virginia Counties}

\author{
Ronda Sturgill \\ University of Tampa \\ Bob Barnett \\ Marshall University \\ Lysbeth Barnett \\ Barnett Ink
}

\begin{abstract}
Kids Win was funded by SAMHSA (Substance Abuse and Mental Health Services Administration) for Cabell, Mason and Wayne Counties in West Virginia. The goal of the project was to develop antiviolence coalitions in the three counties and to develop a strategic plan for a pilot program combating youth violence. The pilot program was designed to use the Second Step and Hazelden Anti-Bullying curricula at the three middle schools. Evaluation methods included a survey of teachers, a survey of students, and a comparison of results of a state mandated school discipline report. All three data sources support the conclusion that violence was reduced significantly because of the Kids Win Program. Kids Win has demonstrated what can be accomplished by teaching students the behavioral skills needed to resolve problems without escalating violence. This program merits replication and expansion and can serve as a model for other programs.
\end{abstract}

\section{Introduction}

Many public health reports show that youth violence continues to be an ongoing and serious problem in communities across the country. The peak year of the youth violence epidemic in the United States was 1993, however, the percentage of youth engaged in violent behavior remains high today. One key to preventing a great deal of youth violence is, "understanding where and when it occurs, determining what causes it, and scientifically documenting which of many strategies for prevention and intervention are truly effective" (Surgeon General's Report on Youth Violence, 2009). An example of a youth program based around anti-violence coalitions in the communities involved is the Kids Win program which targeted youth in three counties in West Virginia. 
A number of other studies have also been conducted on youth violence in similar geographic areas. One example is a study conducted in Pittsburgh, Pennsylvania, which examined the impact of optimistic bias on a school prevention program for middle and high school students. This theory based approach found that despite high profile school shootings, students maintained the belief that violence is less likely to happen to them or their school verse elsewhere in the country (Chapin, 2003). Another study examined different strategies available to schools to address concerns related to school violence. Results from this study recommend effective school violence prevention programs should require comprehensive planning. This comprehensive planning should include documented best-practice programs, preventive strategies, and effective responses to any violence that may occur (Peterson, Larson, and Skiba, 2001). Another example is a whole-school violence prevention program in Connecticut which used a university and public school collaboration. This program was built on elements currently known to support students to learn in a safe environment. This on-going study has recommendations including allowing time for new programs to be developed and placing importance on school-linked services for students (Haymes, 2003).

Youth violence has been an issue in West Virginia in recent years. In 2000, the teen violent death rate was 64.6 per 100,000 children in West Virginia counties combined (Folden, 2002). According to the 1999 Youth Risk Behavior Survey (YRBS) of the number of students living in West Virginia who carried a weapon such as a gun, knife, or club on at least one day during the thirty days prior to the survey was $21.5 \%$ as compared to $17.3 \%$ of the students in the United States. Additionally, $33.1 \%$ of the students living in West Virginia reported they were in a physical fight one or more times during the year prior to the survey (National Center for Chronic Disease Prevention and Health Promotion, 2009). Howwever, in many counties in West Virginia, youth anti-violence activities have been limited and focused on a few individuals at the family level. Ten years ago, the Cabell County Youth Violence Steering Committee was formed to address youth violence issues. The focus for the Kids Win program discussed in this article evolved from this steering committee.

\section{History of Kids Win}

Kids Win is a grant funded project which focused on youth violence prevention in three counties in West Virginia including Cabell, Mason, and Wayne counties. For these three West Virginia counties, Cabell County (population of 96,785) ranked 17, Wayne County (population of 42,903) ranked 28, and Mason county (population of 25,959) ranked 34 out of 55 counties for the teenage violence death rates (Folden, 2002; U.S. Census Bureau, 2009). The project was initiated in response to the Cabell County Youth Violence Steering Committee attempting to develop a three-county youth violence prevention coalition. The goal of the project was to develop anti-violence coalitions in each county and a strategic plan to combat youth violence. The Second Step Program (http://www.cfchildren.org/programs/ssp/overview/), a United States Department of Education Exemplary Program, and the Hazelden Anti-Bullying program (http://www.hazelden.org/web/public/publishing.page), were selected as best practice models. The program committee selected Middle Schools as pilot programs sites.

The project at each middle school included classroom teaching of the Second Step and Hazelden Anti-Bullying curricula by the school coordinators and classroom teachers. Second Step is designed to insert skills-based training into the existing school curricula and encourage the transfer of skills to behavior at school and at home. The curriculum consists of forty-five to fifty minute lessons per week with videos, role-plays and discussions supplementing reading 
and lecture materials. Second Step emphasizes developing empathy, anger management, improving communication and collaborative problem solving skills and conflict resolution skills.

Classroom instruction was supplemented with extracurricular activities such as a Violence Prevention Week, a three county media campaign, and school Youth Anti-Violence Councils. The Youth Councils included peer mediators who were trained in peer mediation and conflict resolution, and an anti-bullying team that served to activate bystanders of bullying incidents to assist in diminishing the bullying problem at each school. In addition, students who were bullies and victims of bullying were referred to the school coordinators for counseling.

\section{Methodology}

The evaluators used a triangulation approach in evaluating the results of the Kids Win Pilot Projects. This approach included using a teacher survey, a student survey, and state-mandated School Discipline Reports.

\section{Kids Win Teacher Survey}

A survey of all teachers at each school was conducted to determine whether the teachers perceived any changes in violence at the school and which program components were most valuable in reducing violence. Eighty-seven teachers completed the survey. The survey was a two-part survey with the first section asking what changes had occurred in nine categories of violent acts (e.g. arguments, gossip and teasing, name-calling or hate speech, bullying, threats or intimidation, stealing or damaging possessions, hitting or kicking, fighting and carrying weapons) and in four more general categories of behavior relating to abilities to respond to violence (e.g. supporting victims of bullying; resolving conflicts peacefully; willingness to report aggressive or inappropriate behavior; and missing school because of fear or victimization). The second section of the survey asked teachers to rate the effectiveness of seven components of the Kids Win Program: the school coordinator, bullying prevention classes, referrals of bullies and aggressive students to the school coordinator, referrals of victimized students to the school coordinator, Violence Prevention Week, Youth Violence Prevention Council, Anti-Bullying Team, and Peer Mediators.

\section{Teacher Ratings of Changes Due to Kids Win Program}

Fifty percent or more of the teachers reported an improvement in each category of reduced school violence. The greatest improvement was in the number of students who were willing to report aggressive behavior with 80 percent of teachers reporting improvement in this category. Over 70 percent of the teachers reported improvement in the number of students who defended victims of aggressive behavior. Additionally, over 70 percent of the teachers reported a reduction in the number of students who hit, kicked or otherwise physically hurt others. Reduced student fighting and stealing were reported by 69 percent of the teachers and in bullying by 68 percent. 
Figure 1

Teacher Ratings of Changes Due to Kids Win Program $(\mathrm{N}=87)$

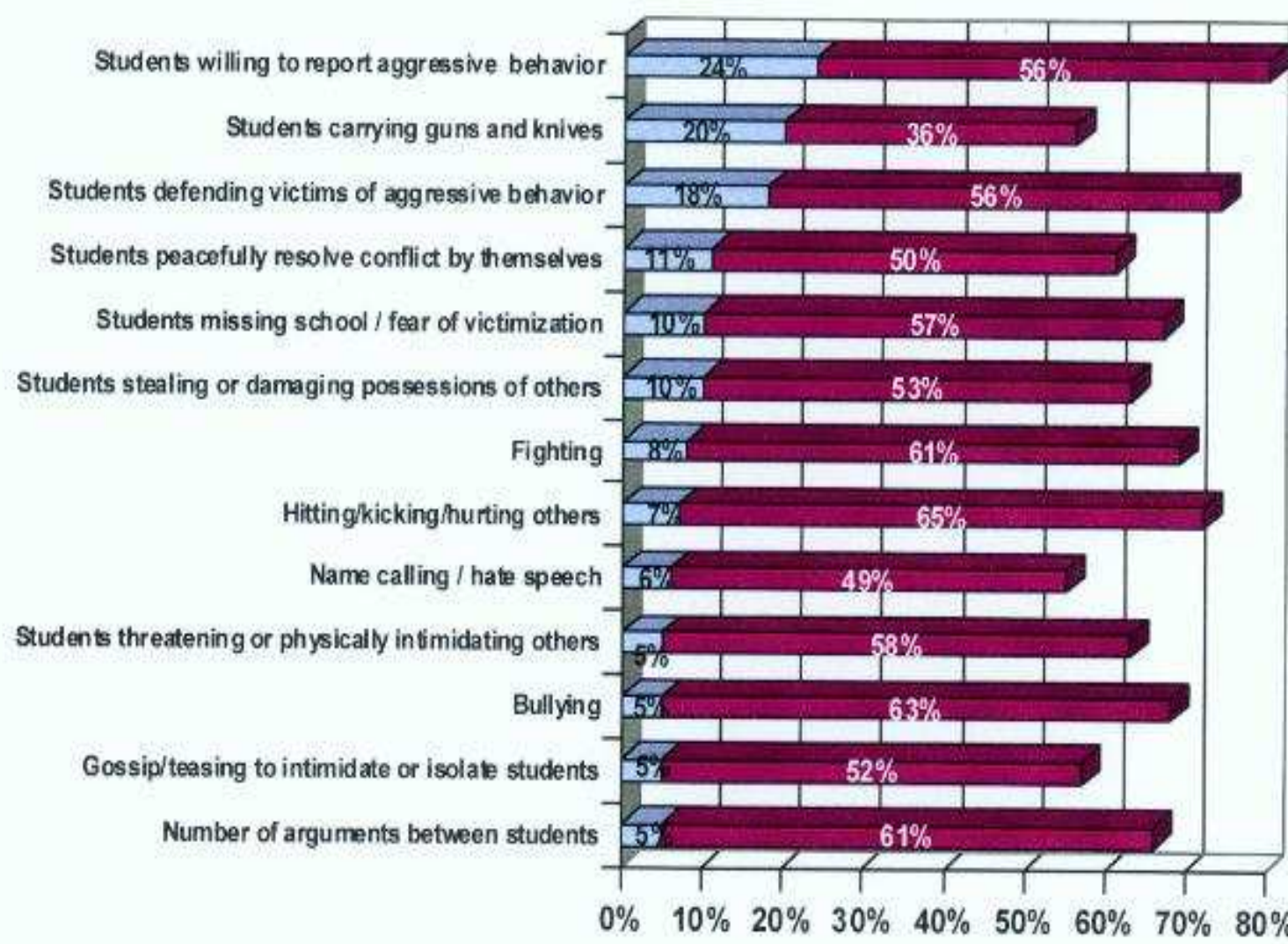

$\square$ Much Improved

Improved

\section{Teacher Ratings of Kids Win School Program Components}

The teachers were overwhelmingly positive in their evaluations of the impact of each aspect of the Kids Win program. Ratings of the program components ranged from 77 percent to 100 percent of the teachers considering them "very valuable" or "somewhat valuable." Teachers ranked having a Kids Win school coordinator (rated valuable by 88 percent) and being able to refer bullies (rated valuable by 86 percent) or to refer victims (rated valuable by 84 percent) to the school coordinator as the most valuable parts of the program. The peer mediators, antibullying teams and Youth Councils were considered valuable by over 60 percent of teachers. 
Figure 2

Teacher Ratings of Kids Win School Program Components $(\mathrm{N}=87)$

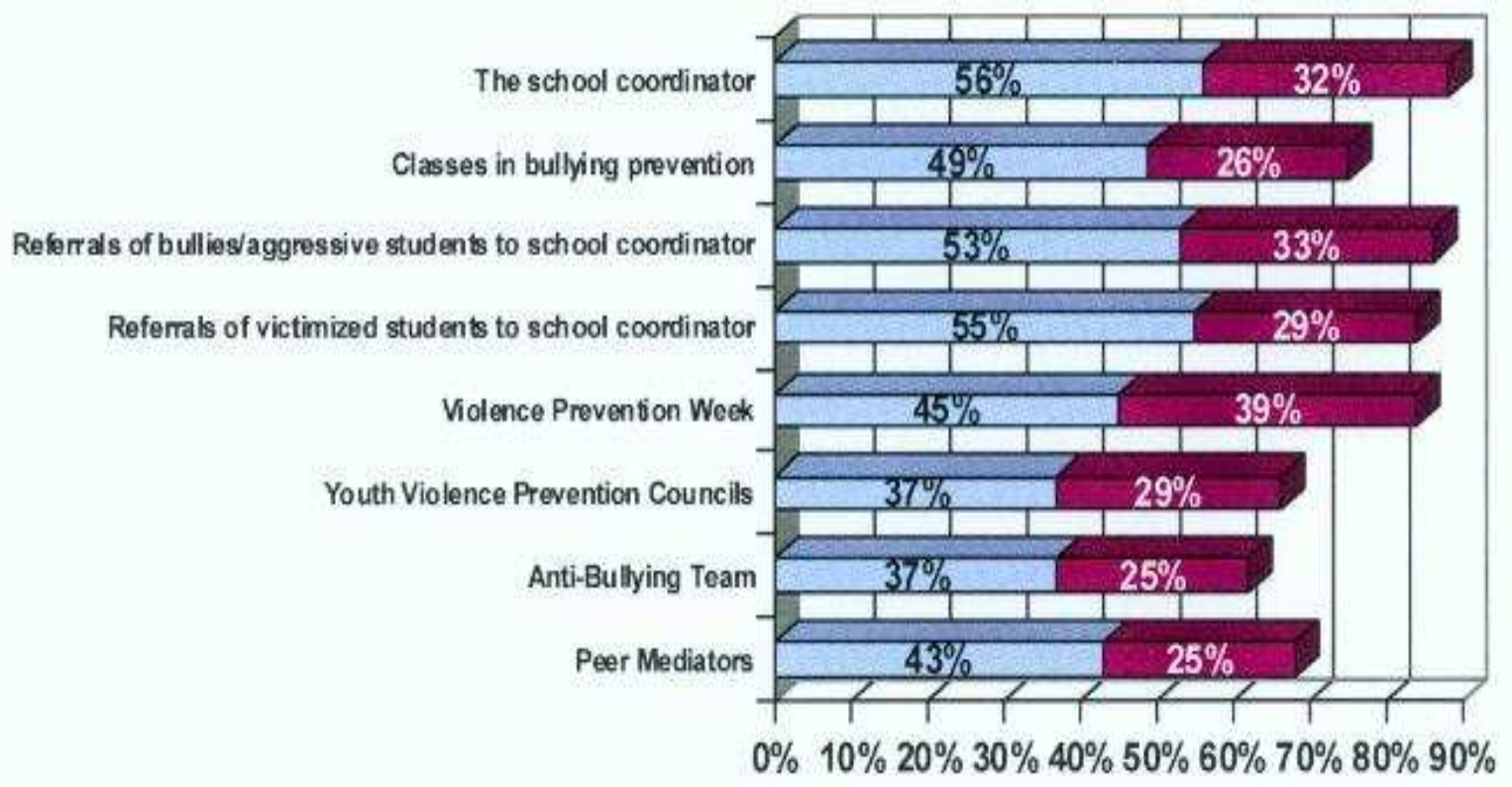

口Very Valuable

Somewhat Valuable

\section{Kids Win Student Survey}

The Kids Win Student Survey was a single pretest - posttest evaluation design using matched pairs. The student surveys were administered at the beginning and at the conclusion of the 2002-2003 Kids Win Program to all students in each school. The outcome analysis was limited to students who completed a survey in both the Fall and Spring semesters. There were 605 students who had survey forms with matching code numbers from each semester without any missing data. Safeguards were used to ensure that individual student responses could not be identified and that confidentiality would be maintained.

A Violence Questionnaire was used to measure the amount of violent behavior engaged in by students, the extent of violence experienced by them (referred to as victimization), where violence occurred and their responses to the violence. The questionnaire also asked whether the students reported violence they experienced or saw, to whom they reported it and if unreported, their reasons for not reporting it (See Figure 3 below). The instrument included twenty items adapted from the California School Climate and Safety Survey (CSCSS) (Furlong, Casas, and Chung, 1996). A School Climate Survey was also adapted from the Inviting Schools Safety Survey (Shoffner and Vacc, 1999) to measure the students' perceptions and feelings about their schools. The questionnaire consisted of twenty-five questions and used a Lickert Scale to measure student's beliefs. 


\section{Demographics}

Some classes did not complete the surveys during both semesters and some grade levels did not participate at every school. There were 193 (32\%) sixth graders, $223(37 \%)$ seventh graders and 189 (31\%) eighth graders included in responding. Each grade level represented about one-third of the matched pairs and demographics of the matched pairs were similar to those of the entire group completing the sample.

\section{Comparison of Violent Actions Before and After Kids Win}

The Total Violence Scores indicated that $322(53 \%)$ students engaged in fewer violent acts after a year of participation in Kids Win. Fifty-eight (9\%) of students had no change in their scores and $227(38 \%)$ reported more violent acts in the Spring than in the Fall. The number of students engaging in fewer violent acts after Kids Win is statistically significant (Wilcoxon signed ranks test $p<.0001)$. The Total Violence Scores could range from zero, that is no violent acts were committed, to the maximum score possible of forty, that is 7+ violent acts were committed in all ten categories. Before Kids Win, scores ranged from zero to forty, but after Kids Win the range was zero to twenty-nine, suggesting that the most violent students had decreased the frequency of their violent activities. The mean Total Violence Score dropped from 8.45 before Kids Win, to a mean of 7.4 after Kids Win $(p=.0001)$. The evidence clearly shows that over half the students decreased their violent activities and the amount of decrease was greater than could be explained by chance. There was also a decrease in the percentage of students who engaged in each of the ten categories studied in this project. The following figure shows students who committed violent acts before and after Kids Win.

Figure 3

Comparison of Percent of Students Engaging In

Violent Acts Before and After Kids Win (N=605)

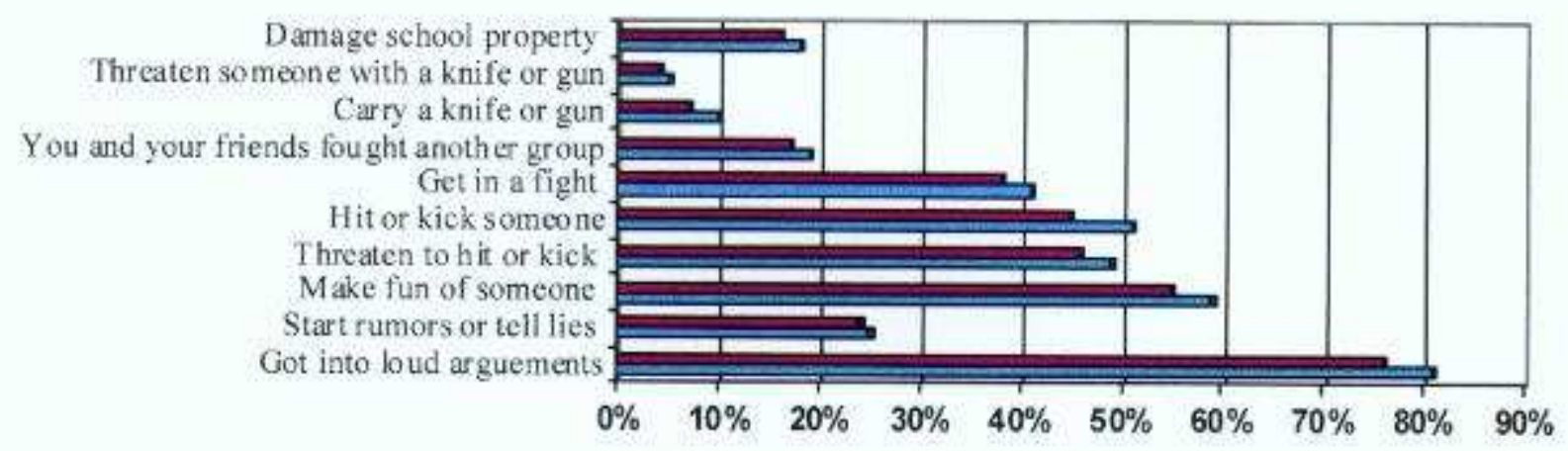

Before Kids Win

After Kids Win

There was consistency across the board in violence reduction. Physical violence declined in several of the areas. There was a 13 percent decrease in students who were in group fights when comparing the students who engaged in activities each semester. Additionally, 11 percent less were in individual fights and 12 percent fewer students hit, kicked or slapped others. Sixteen percent fewer students damaged school property after the program than before the program. 
Sixteen percent fewer students carried a knife or gun after Kids Win. This is a particularly important change. In the fall, about a third of the students reported carrying a knife or gun. Many students did not bring them to school and only used them for hunting, fishing and other outdoor activities. This is an important part of the local culture and many families in rural areas rely on hunting and fishing for food; it is unlikely that students will stop these activities. Potential problems lie in the misuse of weapons. In the year before Kids Win, 5 percent of the students, who carried a weapon, went on to threaten others with it and 4 percent did so after Kids Win began. In addition, 10 percent of students reported bringing weapons to school in the year before Kids Win and 7 percent of students did so after Kids Win had started.

\section{School Climate Survey}

In reviewing the School Climate results, the majority of students responded that they feel safe in their schools. However, the data does not indicate that the school climate became more positive after Kids Win. Student ratings of their schools changed very little from the fall to the spring survey. There was no clear across the board trend in ether a positive or negative direction where the change did occur. Although the present analysis focuses on the 605 matched pairs, it should be noted that the ratings by all students who completed the spring survey were slightly more positive than those of the matched pairs. Overall, ratings for positive aspects of the school climate improved for four factors and declined for seven factors.

Responses to specific questions about perceived safety were mixed. Despite the fact that over 65 percent of students feel safe at school, over half report that that there are places at the school where students don't feel safe and about 40 percent reported some students are afraid to go to the bathroom. Bus safety was somewhat improved and over 60 percent felt safe there after Kids Win.

The five factors that students said were present most frequently were the same before and after Kids Win. These top five factors (see below) that students felt were "always" or "sometimes" present were there are after-school activities, everyone has a fair chance to participate, teachers care about students, I feel safe at school, and grown-ups at school help with problems.

\begin{tabular}{|l|r|r|}
\hline \multicolumn{1}{|c|}{ Factors } & $\begin{array}{l}\text { Percentage } \\
\text { of Students } \\
\text { in the Fall }\end{array}$ & $\begin{array}{l}\text { Percentage } \\
\text { of Students } \\
\text { In the Spring }\end{array}$ \\
\hline Decline in aspects of school climate..... & $84 \%$ & $77 \%$ \\
\hline There are after school activities & $74 \%$ & $72 \%$ \\
\hline Everyone has a fair chance to participate & $72 \%$ & $68 \%$ \\
\hline Teachers care about students & $68 \%$ & $66 \%$ \\
\hline I feel safe at school & $67 \%$ & $65 \%$ \\
\hline Grown-ups at school help with problems & & \\
\hline
\end{tabular}

In general, the negative factors did not change much either. The negative factors students most frequently reported being "always" or "sometimes" present were students start rumors/tell lies to make others feel bad, students are often bored, people make fun of students who were different, and teachers and principals yell at students a lot. 


\begin{tabular}{|l|c|c|}
\hline \multicolumn{1}{|c|}{ Factors } & $\begin{array}{l}\text { Percentage } \\
\text { of Students } \\
\text { in the Fall }\end{array}$ & $\begin{array}{l}\text { Percentage } \\
\text { of Students } \\
\text { In the Spring }\end{array}$ \\
\hline Students start rumors/tell lies to make others feel bad & $78 \%$ & $76 \%$ \\
\hline Students are often bored & $71 \%$ & $76 \%$ \\
\hline People make fun of students who were different & $67 \%$ & $64 \%$ \\
\hline Teachers and principals yell at students a lot & $63 \%$ & $64 \%$ \\
\hline
\end{tabular}

\section{School Discipline Report}

The school discipline report is a state-mandated annual report of the number of students committing various types of offenses. The offenses are documented for each school year and the school discipline records are maintained by the principal for each school and sent to the West Virginia Department of Education. These reports could provide for an excellent basis for a longitudinal comparison of the number of violent activities that occurred at each school as well as a comparison of the current levels of violent activity reported by different schools. However, longitudinal comparisons are difficult because the State Department of Education changed a number of codes between the years and many schools do not record the data in the same way. Additionally, not every school records the data in exactly the same way even though the coding categories are the same.

\section{School Discipline Reports for the Pilot Schools}

Violence was dramatically reduced at Pt. Pleasant Middle School during the 2002-03 school year. In an October 2003 interview, the principal for the previous five years, said, "We had a huge reduction in fighting last year. We used to average about 8 fights a month and in the last four months of last year we did not have any. This year we had our first fight of the year in mid-October." She added, "We think that it was because of the Kids Win program and the Character Class we added last year....The conflict resolution and anti-bullying were very effective...We did everything we could to keep as much of the program as possible this year."

Concerning Wayne Middle School, in an October 2003 interview with assistant principal in charge of discipline stated, "we had many fewer fights and less violence than last school year" (2002-03). He was certain that fighting and violence had declined and attributed it to the program stating "the peer mediation and conflict resolution really worked. You could see that the attitude of the kids really changed. In talking with them after they went through peer mediation, I could see that they had a change in attitude." He was extremely pleased with the impact of Kids Win and complimentary about the school coordinator.

The Cammack Middle School Discipline Report showed a reduction in most categories of violent offences. Physical violence decreased sharply in that physical assault on students decreased by 32 percent from seventy-four to fifty. There was also a decrease in physical assaults of school employees from nine to two incidents.

\section{Conclusions}

To get an accurate picture of how the Kids Win Programs affected violence at the pilot schools, it was essential to include data from a number of sources. The student surveys were crucial because a great deal of violence and victimization is not reported or observed by adults. In addition, measuring the difference between the same student's responses in the Fall and in the 
Spring increased the accuracy of measuring how much change had taken place for each student. Nevertheless, middle school students' ability to reliably assess and report these facts is open to question and it was important to verify their impressions. Teachers are the adults most likely to hear about violence and to observe it; consequently their assessment was an important subjective measure to compare with students' self-reports. Finally, the School Discipline Reports provide a fairly standard metric that is used by all schools in the state. The School Discipline Report is a more objective measure that can be compared with data from the more subjective sources as well as to track changes longitudinally.

All three data sources support the conclusion that violence was reduced significantly because of the Kids Win Program. Looking at the changes in behavior of the individual students themselves, Kids Win clearly made an important difference. The reduction in violent acts reported by students is consistent with the impressions of teachers and the records of violent acts in the School Discipline Reports except that the teachers and School Discipline Reports show a greater reduction in violence than the students reported.

\section{Recommendations}

Kids Win has demonstrated what can be accomplished by teaching students the behavioral skills needed to resolve problems without escalating violence. The Second Step Program (referred to as anti-bullying classes in the local schools) emphasized teaching communication skills and conflict resolution techniques within the context of bullying. Once students had learned an alternative to escalating the level of aggressiveness in conflict situations, they reduced the amount of physical violence that they engaged in. Even though the Second Step Program states that it will take three years to accomplish significant change, the Kids Win Programs were able to bring about important and statistically significant reductions in violence in only one year. The pilot programs have accomplished this in schools with relatively strictly mandated policies and curricula. They have accomplished this by targeting specific behaviors rather than by attempting to change the underlying climate of the school. It is particularly important that in Appalachia, where the local culture supports carrying weapons and fighting, Kids Win has been able to successfully teach an alternative approach. This program merits replication and expansion and can serve as a model for future programs.

\section{References}

Chapin, J. (2003). Unrealistic Optimism and School Violence Prevention Programs. North American Journal of Psychology 2, 193-203.

Folden, P. (2002). West Virginia Kids Count Data Book: 2001 County Profiles of Child Well-

Being. Trends in Child Well-Being, 1990 to 2000. Kids Count.

Furlong, M., Casas, M., Corral, C., \& Chung, A. (1996). Drugs and School Violence. Education \& Treatment of Children, 20, 263-281.

Haymes, E. (2003). Whole-school Violence Prevention Program: A University Public School Collaboration. Children \& Schools, 25, 121-128.

Hazelden Publishing. (2009, September 23). Retrieved from http://www.hazelden.org/web/public/publishing.page 
National Center for Chronic Disease Prevention and Health Promotion. Youth Risk Behavior Survey. (2009, November 12). Retrieved from http://apps.nccd.cdc.gov/yrbss/

Peterson, R., Larson, J., \& Skiba R. (2001). School Violence Prevention: Current Status and Policy Recommendations. Law \& Policy, 23, 345-372.

Second Step Program. (2009, October 10). Retrieved from

http://www.cfchildren.org/programs/ssp/overview/

Shoffner, M., \& Vacc, N. (1999). Psychometric Analysis of the Inviting School Safety Survey. Measurement \& Evaluation in Counseling and Development, 32, 66-75.

Surgeon General's Report on Youth Violence. (2009, November 12). Retrieved from http://www.surgeongeneral.gov/library/youthviolence

United States Census Bureau. (2009, November 12). Retrieved from http://quickfacts.census.gov

(C) Copyright of Journal of Youth Development Bridging Research and Practice. Content may not be copied or emailed to multiple sites or posted to a listserv without copyright holder's express written permission. However, users may print, download or email articles for individual use. 